\title{
Immunization with the Aeromonas OMP Provides Protection against Aeromonas hydrophila in Goldfish (Carassius auratus)
}

Vijayaragavan Thangaviji ${ }^{1}$, Mariavincent Michaelbabu ${ }^{1}$, Setty Balakrishnan Anand ${ }^{2}$, Paramasamy Gunasekaran ${ }^{2}$ and Thavasimuthu Citarasu ${ }^{1}$,*

${ }^{1}$ Centre for Marine Science and Technology, Manonmaniam Sundaranar University, Rajakkamangalam, Kanyakumari District, Tamil Nadu, India 629502 ${ }^{2}$ NRCBS, School of Biological Sciences, Madurai Kamaraj University, Madurai, Tamil Nadu, India 625021

\begin{abstract}
Aeromonas hydrophila is one of the serious pathogens in ornamental fishes causing hemorrhagic bacterial septicemia leading to inflammation and necrosis of the gastrointestinal tract, kidney, muscle, and spleen. Recent studies demonstrated that immunoproteomic vaccines provide protection against bacterial pathogens in fin fish aquaculture and the vaccines are popular due to its long lasting immunity, safety and low cost versatile characteristics. In this study we used an Outer Membrane Protein (OMP) of Aeromonas hydrophila as a vaccine to provide protection against the pathogen in goldfish (Carassius auratus). We used the extract of Asparagus racemosus as an adjuvant in the vaccine preparation. Surivival and immunological response of the vaccinated fishes (30 and 60 days post vaccination (dpv)), were evaluated after challenge with virulent $A$. hydrophila. The vaccine treated experimental groups significantly improved $(P<0.05)$ the survival at $50 \%$ compared to the controls and had improved immunological responses including phagocytosis, albumin-globulin ratio, serum bactericidal activity, and serum lysozyme activity.
\end{abstract}

Keywords: Aeromonas hydrophila; Outer membrane protein; Immunoproteomic vaccines; Goldfish.

\section{Introduction}

Aeromonas hydrophila infection is a scourge of fresh and warm water fish farming worldwide. The pathogen causes motile Aeromonas septicemia and hemorrhagic bacterial septicemia in fishes causing significant economic losses particularly in China and India [1]. A. hydrophila is a ubiquitous gram-negative, rod-shaped bacterium, has wide range of host susceptibility in cat fish, common carp, goldfish and koi carp. A. hydrophila produces a large variety of extra cellular products (ECP) including haemolysines, aerolysin, cytotoxin and enterotoxin [2,3]. Such factors are thought to be important in the virulence of $A$. hydrophila infection in fish, which are known either as motile aeromonad septicemia [4], or haemorrhagic septicemia [5].

Currently applied treatment protocols against aquatic bacterial pathogens are rather difficult, non effective, costly and cause environmental problems. Even though antibiotics and synthetic drugs give positive effects against pathogen control, they cannot be recommended due to their bad effects such as residual effects, resistant strain developments, biomagnifications and suppression of immunity in host organisms [6].

At the global level, farmers have knowledge of the adverse effect of antibiotics and this has lead to shift to eco-friendly approaches such as use of immunostimulants, vaccine bioremediation etc. Fish vaccination in the aquaculture industry has been considered to be very important in reducing economic losses caused by the disease [7]. Several different kinds of vaccines have been investigated/developed against $A$. hydrophila including whole cell (WC), OMPs, ECPs, LPS and biofilms.

Bacterial outer membrane proteins (OMPs) play a significant role in virulence as they comprise the outermost surface in contact with host cells and are also involved in induction of immune defense factors [8]. Recently, attention has been given to OMPs as a potentially important vaccine component. OMPs are located at host-bacterial interface and are important for host immune responses and as targets for drug therapy [9].

Oral vaccination with biofilm cells of A. hydrophila, elicited a significantly higher immune response and protection in carps. The better performance of the biofilm vaccine was attributed to superior antigen delivery to the lymphoid tissues as demonstrated by antigen localization using monoclonal antibodies [10]. The protective nature of bacterial biofilms was exploited for the development of an effective oral vaccine that can resist gastric destruction of epitopes, facilitating improved antigen delivery [11].

In most vaccines, adjuvants are a crucial ingredient for efficacy. Various adjuvants have been used in fishery and they induce better and more long-lasting protection than non-adjuvant vaccine. Recently the herbal immuno adjuvant Asparagus racemosus has been shown to improve vaccine delivery against aquatic pathogens [12]. A. racemosus, demonstrated significant immuno stimulatory activity particularly at the humoral level in experimental systems. Saponin is the major active immuno adjuvant compounds of $A$. racemosus and they promote peripheral lymphocyte proliferation, enhance serum antibody titer and offer safer advantages than chemical adjuvants [13]. In the present study we demonstrate that the immunoproteomic Aeromonas OMP vaccine in the presence of the herbal adjuvant $A$. racemosus extract could provide protection against $A$. hydrophila in ornamental goldfish (Carassius auratus).

*Corresponding author: Thavasimuthu Citarasu, Centre for Marine Science and Technology, Manonmaniam Sundaranar University, Rajakkamangalam, Kanyakumari District, Tamil Nadu, India.629502; E-mail: citarasu@gmail.com

Received November 30, 2011; Accepted February 25, 2012; Published March 03, 2012

Citation: Thangaviji V, Michaelbabu M, Anand SB, Gunasekaran P, Citarasu T (2012) Immunization with the Aeromonas OMP Provides Protection against Aeromonas hydrophila in Goldfish (Carassius auratus). J Microbial Biochem Technol 4: 045-049. doi:10.4172/1948-5948.1000070

Copyright: (c) 2012 Thangaviji V, et al. This is an open-access article distributed under the terms of the Creative Commons Attribution License, which permits unrestricted use, distribution, and reproduction in any medium, provided the original author and source are credited 
Citation: Thangaviji V, Michaelbabu M, Anand SB, Gunasekaran P, Citarasu T (2012) Immunization with the Aeromonas OMP Provides Protection against Aeromonas hydrophila in Goldfish (Carassius auratus). J Microbial Biochem Technol 4: 045-049. doi:10.4172/1948-5948.1000070

\section{Materials and Methods}

\section{Source of virulent $A$. hydrophila strain}

Virulent strain of Aeromonas hydrophila was isolated in our lab, from infected goldfish (C. auratus). After biochemical confirmation and virulence studies, they were maintained in $-80^{\circ} \mathrm{C}$ as glycerol stock for further studies.

\section{Preparation of Outer Membrane Protein (OMP) vaccine}

Twenty four culture of virulent A. hydrophila were harvested by centrifugation from Tryptic Soy Broth at $3,000 \mathrm{~g}$ for $20 \mathrm{~min}$ at $25^{\circ} \mathrm{C}$. The cell pellets were washed twice in phosphate buffered saline (PBS) and once in $10 \mathrm{mM}$ Tris-hydrochloride ( $\mathrm{pH}$ 7.5). Further cells were re-suspended in Tris- $\mathrm{HCl}$ and sonicated at $50 \mathrm{~W}$, for $30 \mathrm{~s}$, four times on ice. After sonication the suspension was mixed with Sarkosyl for solubilization of the OMP then incubated at $25^{\circ} \mathrm{C}$ for $30 \mathrm{~min}$. After incubation the suspension was centrifuged at $4000 \mathrm{~g}$ for $20 \mathrm{~min}$ and the supernatant was collected. After centrifugation at $45000 \mathrm{~g}$ for 45 min the pellet was collected and stored at $-80^{\circ} \mathrm{C}$ until used. The protein was quantified following the protocol of Lowry et al. [14]. The OMP proteins were resolved on a 10\% SDS-PAGE [15], to generate protein profiles.

\section{PCR amplification of OMP gene}

To amplify the OMP gene from virulent A. hydrophila, primers were designed. The forward primer is: 5' CCC AAGCTTATG GCAGTGGTTTATGACAAA 3' and the reverse primer is 5' AACTGCAGTTAGAAGTTGTATTGCAGGGC 3'. PCR amplification was performed using $100 \mathrm{ng}$ bacterial genomic DNA in a $100 \mu \mathrm{l}$ reaction mixture containing $1 \mathrm{X}$ amplification buffer, $1.5 \mathrm{mM} \mathrm{MgCl}, 0.4 \mathrm{mM}$ dNTPs and $1 \mu \mathrm{m}$ each primers with 5 Units of Taq DNA polymerase. PCR was performed in Master cycler (Eppendorf, Germany) programmed for 33 cycles, with an initial denaturation at $94^{\circ} \mathrm{C}$ for 5 min and each cycle with denaturation at $94^{\circ} \mathrm{C}$ for 30 second, annealing at $50^{\circ} \mathrm{C}$ for $1 \mathrm{~min}$; extension at $72^{\circ} \mathrm{C}$ for $1 \mathrm{~min}$; Final extension at $72^{\circ} \mathrm{C}$ for $5 \mathrm{~min}$; end $4^{\circ} \mathrm{C}$ for $5 \mathrm{~min}$. PCR amplified products were resolved in a $1 \%$ agarose gel by electrophoresis and analyzed using Gel-doc.

\section{Immuno adjuvant}

Asparagus racemosus tubers were extracted with hot water at $100^{\circ} \mathrm{C}$ for two hours. The extracts were filtered and the supernatant were condensed by rotary evaporator at $55^{\circ} \mathrm{C}$, lyophilized and stored at $4^{\circ} \mathrm{C}$. The extracts contain steroidal saponins having immunoadjuvant properties [16].

\section{Vaccine delivery and immunization}

Experimental set-up: Healthy goldfish, Carassius auratus having the mean weight of $30 \pm 2.0 \mathrm{~g}$ were used for this immunization study. They were acclimatized and kept in quarantine tanks for a period of 10 days to assess their disease-free healthy status and fed with commercial feeds. After acclimatizing, triplicate tanks containing a total of sixty fishes $(20$ X $3=60)$ were maintained in each group. The tanks were of $500 \mathrm{l}$ capacity, flow-through aquaria with water flow rate of $1 \mathrm{l} / \mathrm{min}$. Vaccines were injected to the fishes, intraperitonealy once in 10 days. The OMP vaccine was injected at the rate of $2 \mu \mathrm{g} / \mathrm{gram}$ body weight. For immune adjuvant treated groups, $500 \mu \mathrm{g}$ of $A$. racemosus extracts was added to the antigenic proteins. The blank control groups were unvaccinated fishes without bacterial challenge. The control groups consisted of unvaccinated fishes subjected to bacterial challenge. The experimental as well as control fishes were fed with commercial feed twice per day. The detailed vaccine protocols are given in the Figure 1.

\section{Challenge with virulent $A$. hydrophila}

On 30 and 60 days post vaccination (dpv), group of fishes were challenged with a lethal dose of $A$. hydrophila $\left(1 \times 10^{7}\right)$ by injecting intramuscularly and transferring to a new $250 \mathrm{l}$ aquaria. The fishes were observed for the cumulative mortality and other pathological signs for 5 days. Blood was collected from the un-challenged, challenged and moribund fishes for immunological studies.

\section{Immunological studies}

After 30 and $60 \mathrm{dpv}$ fish samples were chosen from each experiment and control group, and anaesthetized with $50 \mathrm{mg} \mathrm{MS}-222 / \mathrm{dm} 3$ of water, and used for blood collection. Blood was collected from caudal vein, with $1 \mathrm{ml}$ plastic syringe rinsed with anticoagulant, and a part of the blood was transferred immediately, added to an equal volume of $10 \%$ tri sodium citrate, and stored at $4^{\circ} \mathrm{C}$. The remaining blood was kept at room temperature for $1 \mathrm{~h}$ without anticoagulant to collect the serum and stored at $-40^{\circ} \mathrm{C}$.

Phagocytosis was performed following the method of Park and Jeong [17], using formalin killed A. hydrophila at the rate of $10^{7} \mathrm{cfu} /$ $\mathrm{ml}$ with $0.1 \mathrm{ml}$ of blood samples of each groups. To study the serum bactericidal activity, five fishes from each group were injected with 0.1 $\mathrm{ml} / \mathrm{kg}$ body weight with live virulent $A$. hydrophila suspension at the rate of $10^{5}$ cells $/ \mathrm{ml}$ ) and blood samples were collected 10 and $90 \mathrm{~min}$ after injection. One hundred micro liters of blood was serially diluted and plated in the aeromonas agar (Hi media, India). The albumin-globulin ratio (A-G) of the sera was calculated following the method of Sahoo et al. [18]. The serum samples were analyzed for total protein following the dye-binding method of Bradford [19], using bovine serum albumin as standard, for albumin by the bromocresol green method, and for

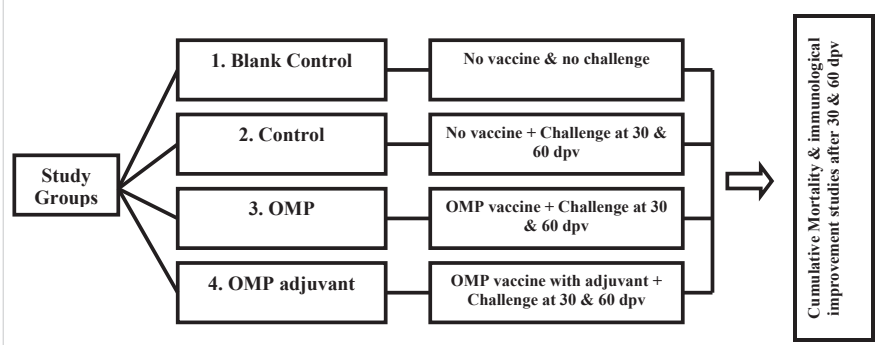

Figure 1: Experimental design for OMP vaccine preparation and delivery methods to ornamental goldfish $C$. auratus.

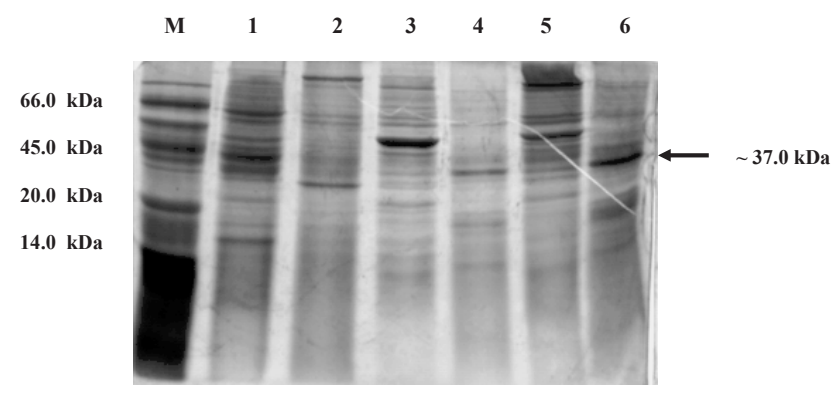

Figure 2: Outer Membrane Protein (OMP) profile of virulent $A$. hydrophila isolated from ornamental goldfish $C$. auratus. M: marker; lane 1: Virulent $A$. hydrophila whole cells isolated from Carp; lane 2: OMP of Virulent $A$. hydrophila whole cells isolated from Carp; lanes 3: A. hydrophila MTCC strain; Lane 4: OMP of $A$. hydrophila MTCC strain; Lane 5: Virulent $A$. hydrophila whole cells isolated from $C$. auratus and Lane 6: OMP of $A$. hydrophila isolated from $C$. auratus. The arrows indicated the corresponding OMP proteins. 
Citation: Thangaviji V, Michaelbabu M, Anand SB, Gunasekaran P, Citarasu T (2012) Immunization with the Aeromonas OMP Provides Protection against Aeromonas hydrophila in Goldfish (Carassius auratus). J Microbial Biochem Technol 4: 045-049. doi:10.4172/1948-5948.1000070

globulin by subtracting the albumin value from the total protein value. Finally, the albumin-globulin ratio (A-G) was calculated. Lysozyme activity was measured according to methods described by Ellis [20]. One hundred micro liter of serum was mixed with $2 \mathrm{ml}$ Micrococcus luteus suspension at $10^{8} \mathrm{cfu} / \mathrm{ml}$ of $0.05 \mathrm{M}$ sodium phosphate buffer $(\mathrm{pH}$ 6.2). The mixture was incubated at $25^{\circ} \mathrm{C}$, and its $\mathrm{OD}$ was measured at $530 \mathrm{~nm}$ using a spectrophotometer. One unit of Lysozyme activity was defined as the amount of enzyme producing a decrease in absorbance of $0.001 \mathrm{~min} / \mathrm{ml} / \mathrm{serum}$

\section{Statistical analysis}

All data obtained from experiments were analyzed using one way ANOVA $(\mathrm{P}<0.01$ as significant level) in Statistica 6.0 computer package (Statsoft, UK). Means were also compared using SNK test.

\section{Results and Discussion}

\section{Outer Membrane Protein (OMP)}

The outer membrane protein (OMP) profiles of the virulent $A$. hydrophila isolated from infected carp as well as goldfish and the nonvirulent strain from Microbial Type Culture Collection (MTCC) are shown in Figure 2. The OMP profile revealed that, there is a polypeptide having a molecular weight of around $37 \mathrm{kDa}$ in all the three $A$. hydrophila strains and among these strains, the A. hydrophila which was isolated from goldfish had high expression of OMP protein. As goldfish had high expression of OMP protein we used bacteria isolated from goldfish to isolate OMP in our study. The PCR amplification of the OMP gene revealed that, the product was successfully amplified at $1008 \mathrm{bp}$ in the genomic DNA isolated from A. hydrophila isolated from goldfish. Unfortunately there is no amplification found in the MTCC and isolates of Carp (Figure 3). Quin et al. [21] isolated three carbohydrate reactive OMP (CR-OMP) having the molecular weight of 43, 40 and $\sim 14 \mathrm{kDa}$ from the A. hydrophila strain A6 by affinity chromatography. OMPs act as an adhesin and contribute to the virulence. An immunoreactive antigen of the outer membrane protein of A. hydrophila was isolated from goldfish, C. auratus by Maji et al. [22]. Also Khushiramani et al. [9] isolated 3 to 4 high intensity OMP bands from 40 strains of $A$. hydrophila had the range between 25 to 45 $\mathrm{kDa}$.

\section{OMP Vaccines and Challenge}

The fishes from 30 and $60 \mathrm{dpv}$ control groups were succumbed to death $100 \%$ within 5 days after pathogenic A. hydrophila challenge (Figure $4 \mathrm{a} \& \mathrm{~b}$ ). The percentage of cumulative mortality was decreased significantly $(\mathrm{P}<0.01)$ in the experimental vaccines treated groups. After $30 \mathrm{dpv}$, the OMP vaccines helped to decrease the cumulative mortality to $40 \%$, the OMP with adjuvant decreased the cumulative mortality $30 \%$ after A. hydrophila challenge. The same manner was reflected in the $60 \mathrm{dpv}$ (Figure 4b), the immunoadjuvant help to decrease the cumulative mortality of $20 \%$. Recently attention has been given to the immunoproteomic vaccines such as bacterial outer membrane proteins (OMP) [23], vaccine to favour highly immune responses against the bacterial as well as viral pathogens. Adjuvant can be used to improve the immune response to vaccine antigens for several different purpose, including increasing the immunogenicity of weak antigens, enhancing the speed and duration of the immune response, modulating antibody activity, specificity, isotope (or) subclass distribution, stimulating cell mediated immunity, enhancing immune responses in immunologically immature or senescent individuals and decreasing the dose of antigen competition in combination vaccines [24]. Asparagus racemosus has been used as a good adjuvant in human

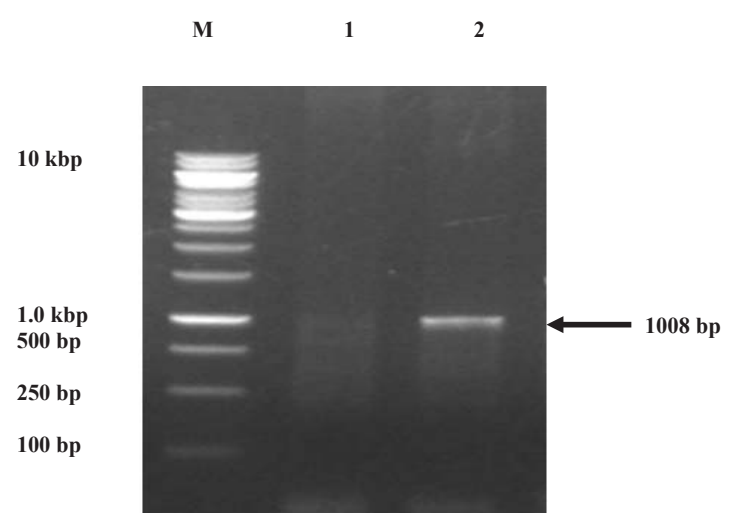

Figure 3: PCR amplification of OMP gene from virulent $A$. hydrophila isolated from ornamental goldfish C. auratus. M- DNA marker; Lane 1- Negative control; lane 2- PCR amplified product, $1008 \mathrm{~kb}$.

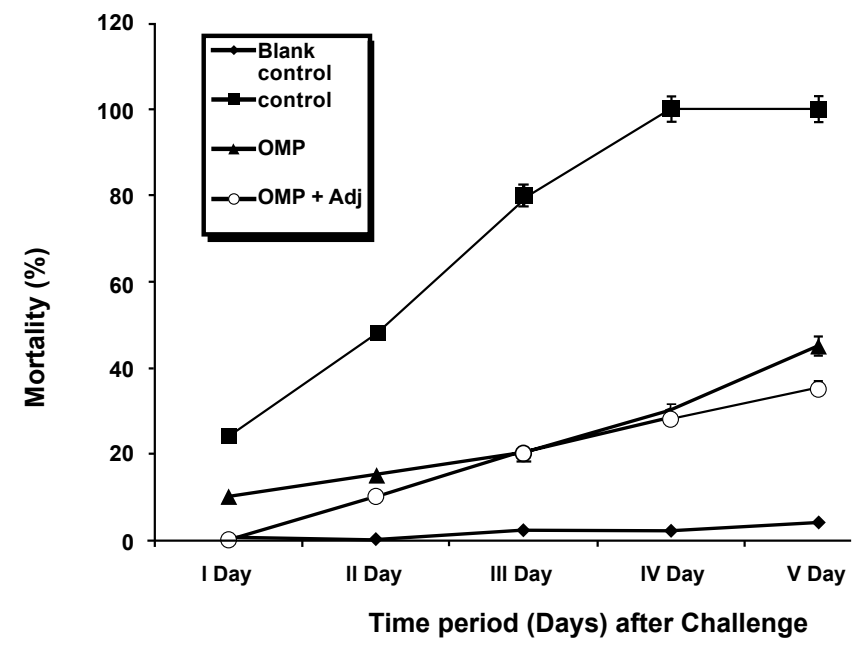

Figure 4a: Cumulative mortality (\%) of OMP vaccine treated goldfish $C$. auratus against virulent $A$. hydrophila challenge after $30 \mathrm{dpv}$.

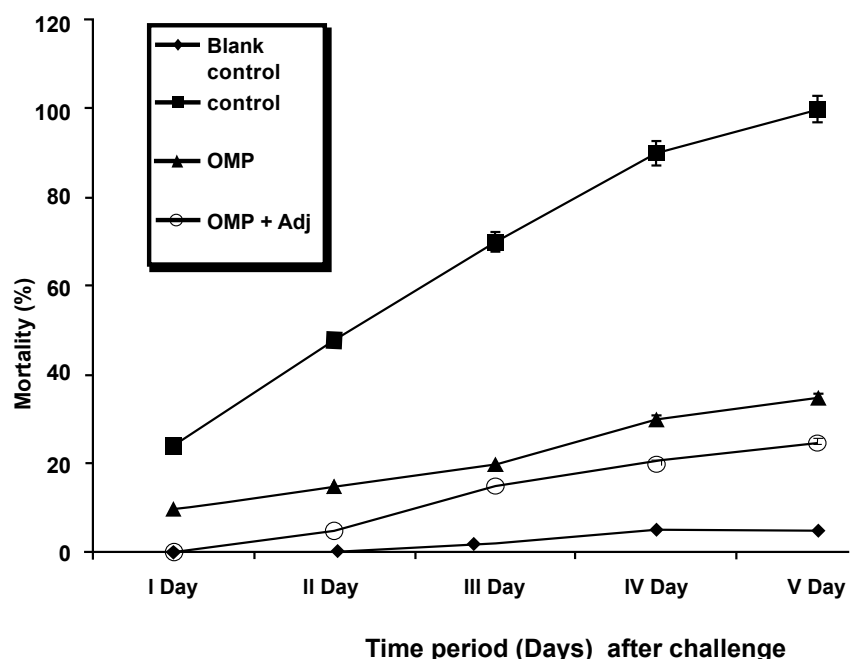

Figure 4b: Cumulative mortality (\%) of OMP vaccine treated goldfish $C$ auratus against virulent $A$. hydrophila challenge after $60 \mathrm{dpv}$. 
Citation: Thangaviji V, Michaelbabu M, Anand SB, Gunasekaran P, Citarasu T (2012) Immunization with the Aeromonas OMP Provides Protection against Aeromonas hydrophila in Goldfish (Carassius auratus). J Microbial Biochem Technol 4: 045-049. doi:10.4172/1948-5948.1000070

diseases [25], and give an efficient and sustained immunostimulation to improve immunogenicity of weak or low dose of antigens. The OMP vaccines helped to decrease the cumulative mortality to $30 \%$ and the OMP with adjuvant had to $20 \%$ after $A$. hydrophila challenge. Among the different period of vaccinations, the efficacy increased when the prolonged period of vaccine treatment was done. The immunoadjuvant potential of $A$. racemosus aqueous root extract was evaluated by [16], in Bordtella pertussis immunized with diphtheria, tetanus, pertussis (DTP) vaccine, and resulted significant increase in antibody titers. Anbarasu et al. [26], found that formalin inactivated vaccines were superior to heat killed preparations, especially when the bacterins were injected with adjuvants. Thune and Plumb [27], found that both sac fry and swim-up fry vaccinated by immersion in sonicated polyvalent bacterin were protected against challenge with homologous bacteria, indicating an early onset of immunocompetence in channel catfish. Also humoral and protective responses of oral administration of an Aeromonas hydrophila biofilm vaccine in three species of carp, catla (Catla catla Ham.), rohu (Labeo rohita Ham.), and common carp (Cyprinus carpio Lin.) were studied by Azad et al. [10] and got higher antibody production against the pathogenic challenge.

\section{Immunological Studies}

Immunological responses were analyzed from the serum and blood cells of the 30 and $60 \mathrm{dpv}$ vaccinated goldfish after A. hydrophila challenge (Table 1). The percentage of phagocytic activity showed a significant variance $(\mathrm{P}<0.01)$ between the control and vaccine treated goldfish after $A$. hydrophila challenge. In the unvaccinated, control group, around $46 \%$ of the A. hydrophila cells was phagocytosed and the percentage was drastically decreased to $28 \%$ when no vaccination was given after challenge. The experimental vaccines groups significantly $(\mathrm{P}<0.01)$ increased the percentage of phagocytosis compared to the control group (Table 1). Similar results were observed in 60dpv after $A$. hydrophila challenge. Increased value of A- G ratio in vaccine treated groups indicated immune responses due to vaccine and adjuvant. The A-G ratio increased in vaccinated fishes in both $30 \mathrm{dpv}$ and $60 \mathrm{dpv}$ compared to unvaccinated fishes. The herbal adjuvant $A$. racemosus helped to boost the immune system along with OMP vaccines. There was a higher A-G ratio observed with prolonged vaccine treatments. Our study demonstrated that the OMP vaccines helped to improve the immunological parameters in the presence of the immunoadjuvants. The immunoadjuvant $A$. racemosus in vaccines may activate the antigen presenting cells (e.g. macrophages) to produce cytokines which can activate lymphocytes producing specific antibodies. Numerous studies have reported the contribution of adjuvant to immune response in fishes [28]. Most of studies demonstrated that adjuvant could enhance immune response through increasing activity of leucocyte and plasmocyte as well as speeding up production of specific antibody [29]. Cuesta et al. [30], had investigated the propolis on the innate immune responses of gilthead sea bream, and found that it has limited immunostimulatory effects although intraperitoneal administration was more effective than dietary intake. The results of this work found that the propolis has immunostimulatory function and were consistent with others. Tatefuji et al. [31], reported that the compounds of propolis could enhance macrophage mobility and spreading. Due to the saponins active nature of the herbal immuno adjuvant $A$. racemosus it may be greatly improve the induction of major histocompatibility complex (MHC) class I-restricted CD81 cytotoxic T lymphocyte (CTL) responses.

Serum bactericidal activity also significantly $(\mathrm{P}<0.01)$ improved than the control group due to immune enhancement given by vaccines. The activity increased more than four times in all vaccine treated groups. Serum Lysozyme activity of 23.75 and $26 \mathrm{IU} / \mathrm{ml}$ were observed in zero vaccination group after $30 \mathrm{dpv}$ and $60 \mathrm{dpv}$ respectively. The activity increased significantly $(\mathrm{P}<0.01)$ as 35.75 and $38 \mathrm{IU} / \mathrm{ml}$ in OMP and OMP with adjuvant respectively of $30 \mathrm{dpv}$ groups. Similar results were observed in the serum lysozyme activity of $60 \mathrm{dpv}$. IgY edible antibody raised with the herbal adjuvant $A$. recemosus as good vaccine candidate for improving serum bactericidal as well as lysozyme activity against WSSV infection in P. monodon [12]. The herbal immunostimulants also enhance the serum bactericidal and lysozyme activity against $V$. harveyi infection in grouper (Ephinephelus tauvina) [32, 33].

\section{Conclusion}

The active principles of the $A$. racemosus help to improve immunity during vaccination. OMP vaccine combined with the herbal adjuvant from $A$. racemosus is effective in providing protection against $A$. hydrophila infection in goldfish (C. auratus). The Aeromonas OMP antigenic protein could be used as a potential vaccine to control $A$. hydrophila in fishes.

\section{Acknowledgements}

V. Thanga Viji acknowledges the UGC-Networking Resource Centre in Biological Sciences (NRCBS), School of Biological Sciences, Madurai Kamaraj University, India for financial support (NRCBS visiting fellowship during August to September 2009)

\begin{tabular}{|c|c|c|c|c|c|c|c|c|}
\hline \multirow{3}{*}{ Treatments } & \multicolumn{8}{|c|}{ Immunological parameters } \\
\hline & \multicolumn{2}{|c|}{ Phagocytosis (\%) } & \multicolumn{2}{|c|}{ Albumin Globulin ratio } & \multicolumn{2}{|c|}{$\begin{array}{c}\text { Serum Bactericidal } \\
\text { Activity (\%) }\end{array}$} & \multicolumn{2}{|c|}{$\begin{array}{l}\text { Serum Lysozyme } \\
\text { Activity (IU/ml) }\end{array}$} \\
\hline & $30 \mathrm{dpv}$ & $60 \mathrm{dpv}$ & $30 \mathrm{dpv}$ & $60 \mathrm{dpv}$ & $30 \mathrm{dpv}$ & $60 \mathrm{dpv}$ & $30 \mathrm{dpv}$ & $60 \mathrm{dpv}$ \\
\hline Blank Control & $\begin{array}{c}46.74^{\mathrm{a}} \\
\pm \\
1.43\end{array}$ & $\begin{array}{c}47.88^{\mathrm{a}} \\
\pm \\
3.33\end{array}$ & $\begin{array}{c}3.33 \\
\pm \\
0.04^{\mathrm{a}}\end{array}$ & $\begin{array}{c}2.99 \\
\pm \\
0.05^{\mathrm{a}}\end{array}$ & $\begin{array}{c}6.34 \\
\pm \\
0.25^{a}\end{array}$ & $\begin{array}{c}5.97 \\
\pm \\
0.64\end{array}$ & $\begin{array}{c}34.7 \\
\pm \\
1.5^{\mathrm{a}}\end{array}$ & $\begin{array}{c}37.9 \\
\pm \\
1.5^{a}\end{array}$ \\
\hline Control & $\begin{array}{c}28.33^{b} \\
\pm \\
2.03\end{array}$ & $\begin{array}{c}32.65^{\mathrm{b}} \\
\pm \\
1.76\end{array}$ & $\begin{array}{c}1.07 \\
\pm \\
0.05^{\mathrm{b}}\end{array}$ & $\begin{array}{c}1.33 \\
\pm \\
0.02^{b}\end{array}$ & $\begin{array}{c}4.06 \\
\pm \\
0.04^{b}\end{array}$ & $\begin{array}{c}3.55 \\
\pm \\
0.01^{b}\end{array}$ & $\begin{array}{c}23.75 \\
\pm \\
2.33^{b}\end{array}$ & $\begin{array}{c}26.55 \\
\pm \\
1.09 \text { b }\end{array}$ \\
\hline OMP & $\begin{array}{c}48.73^{a} \\
\pm \\
2.33 \\
\end{array}$ & $\begin{array}{c}51.34^{\mathrm{c}} \\
\pm \\
3.98\end{array}$ & $\begin{array}{c}4.27 \\
\pm \\
0.59^{c}\end{array}$ & $\begin{array}{l}5.07 \\
\pm \\
0.9^{c}\end{array}$ & $\begin{array}{c}9.77 \\
\pm \\
0.95^{c}\end{array}$ & $\begin{array}{c}11.23 \\
\pm \\
1.23^{c}\end{array}$ & $\begin{array}{c}35.95 \\
\pm \\
2.59^{a}\end{array}$ & $\begin{array}{c}39.02 \\
\pm \\
1.45^{\mathrm{c}}\end{array}$ \\
\hline $\mathrm{OMP}+\mathrm{Adj}$ & $\begin{array}{c}54.63^{\circ} \\
\pm \\
1.69\end{array}$ & $\begin{array}{c}55.78^{\mathrm{d}} \\
\pm \\
3.0\end{array}$ & $\begin{array}{c}5.08 \\
\pm \\
0.84^{d}\end{array}$ & $\begin{array}{c}7.2 \\
\pm \\
0.55^{\mathrm{d}}\end{array}$ & $\begin{array}{c}13.65 \\
\pm \\
1.03^{d}\end{array}$ & $\begin{array}{l}15.65 \\
\pm \\
2.89^{d}\end{array}$ & $\begin{array}{c}38.50 \\
\pm \\
2.2^{\mathrm{c}}\end{array}$ & $\begin{array}{c}43.22 \\
\pm \\
2.98^{d}\end{array}$ \\
\hline
\end{tabular}

Table 1: Immunological studies of OMP vaccine treated goldfish $C$. auratus against virulent $A$. hydrophila challenge after 30 and 60 dpv. Values with the same superscript do not differ significantly from each other $(P<0.01)$. 
Citation: Thangaviji V, Michaelbabu M, Anand SB, Gunasekaran P, Citarasu T (2012) Immunization with the Aeromonas OMP Provides Protection against Aeromonas hydrophila in Goldfish (Carassius auratus). J Microbial Biochem Technol 4: 045-049. doi:10.4172/1948-5948.1000070

\section{References}

1. Austin B, Austin DA (1987) In: Laird LM, editor. Bacterial fish pathogens: disease in farmed and wild fish, Chichester, England: Ellis Horwood Limited p. 111-195.

2. Allan B J, Stevenson RMW (1981) Extracellular virulence factors of Aeromonas hydrophila in fish infections. Can J Microbiol 27: 1114-1122.

3. Boulanger Y, Lallier R, Cousineau G (1977) Isolation of enterotoxigenic Aeromonas from fish. Can J Microbiol 23: 1161 - 1164.

4. McDaniel D (1979) Procedures for the detection and identification of certain fish pathogen. American Fisheries Society Bethesda, Maryland, 118p.

5. Sneieazko SF, Piotrowaka W, Kocylowski B, Merek K (1983) Bacterial and serological studies on bacteria of the carp hemorrhagics septicemia. Fish jagellonia univ. Krakow, Poland, 30p.

6. Citarasu T, Raja Jeya Sekar R, Babu MM, Marian MP (2002) Developing Artemia enriched herbal diet for producing quality larvae in Penaeus monodon. Asian Fisheries Science 15: 21-32.

7. Ellis A E, do Vale A, Bowden TJ, Thompson K, Hastings TS (1997) In vivo production of A-protein, lipopolysaccharide, iron-regulated outer membrane proteins and $70-\mathrm{kDa}$ serine protease by Aeromonas salmonicida sub $\mathrm{sp}$. salmonicida. FEMS Microbiol Lett 149: 157-163.

8. Ebanks RO, Goguen M, McKinnon S, Pinto DM, Ross NW (2005) Identification of the major outer membrane proteins of Aeromonas salmonicida. Dis Aquat Organ 68: 29-38

9. Khushiramani R, Girisha SK, Bhowmick PP, Karunasagark I (2008) Prevalence of different outer membrane proteins in isolates of Aeromonas species. World J Microbiol Biotechnol 24: 2263-2268.

10. Azad IS, Shankar KM , Mohan CV, Kalita B (2000) Uptake and processing of biofilm and free cell vaccines of Aeromonas hydrophila in Indian major carps and common carp following oral vaccination-antigen localization by a monoclonal antibody. Dis Aquat Organ 43:103-108.

11. Johnson KA, Amend DF (1983) Efficacy of Vibrio anguillarum and Yersinia ruckeri bacterin applied by oral and anal incubation of salmonids. Journal of Fish Diseases 6: 473-476.

12. Kumaran T (2010) Immunoadjuvant Efficiency of Asparagus racemosus Extract Against WSSV Infection in Shrimp Aquaculture, Journal of Aquaculture Feed Science and Nutrition 2: 1-5.

13. Patwardhan B (2000) Ayurveda: the designer medicine: review of ethnopharmacology and bioprospecting research. Indian Drugs 37: 213-227.

14. Lowry OH, Rosenberough NJ, Farr AL, Randal RJ (1951) Protein measurement with folinphenol reagent. J Biol Chem 193: 265-275.

15. Laemmli UK (1970) Clevage of structural protein during the assembly of the head of bacteriophage 14. Nature 227: 680-685

16. Gautam M, Diwanay S, Gairola S, Shinde Y, Patki P, et al. (2004) Immunoadjuvant potential of Asparagus racemosus aqueous extract in experimental system, J Ethnopharmacol 91: 251-255.

17. Park KH, Jeong HD (1996) Enhanced resistance against Edwardsiella tarda infection in tilapia Oreochromis niloticus by administration of protein-bound polysaccharhide. Aquaculture 141: 135-143.
18. Sahoo PK, Mohanty J, Mukherjee SC (1999) The three imuunomodulators on haemotological parameters and immunity level in rohu (Labeo rohita) fingerlings. J Aquac Trop 14: 127-135.

19. Bradford MM (1976) A rapid and sensitive method for the quantification of microgram quantities of proteins utilizing the principle of protein dye binding Analytical Biochemistry 72: 248-254.

20. Ellis AE (1988) Fish Vaccination. San Diego: Academic Press.

21. Quinn DM, Wong CYF, Atkinson HM, Flower RLP (1993) Isolation of carbohydrate-reactive outer membrane proteins of Aeromonas hydrophila. Infection and Immunity 61: 371-377.

22. Maji S, Mali $P$, Joardar SN (2006) Immunoreactive antigens of the oute membrane protein of Aeromonas hydrophila, isolated from goldfish, Carassius auratus (Linn.). Fish \& Shellfish Immunology 20: 462-473

23. Bakopoulos V, Adams A, Richards RH (1997) The effect of iron limitation growth conditions on the cell and extra-cellular components of the fish pathogen, Pasteurella piscicida. Journal of Fish Diseases 20: 297- 305.

24. Singh M, O'Hagan DT (2003) Invited review recent advances in veterinary vaccine adjuvants. Int J Parasitol 33: 469-478.

25. Samhita C (1949) Translator. Shree Gulabkunverba Ayurved Society, Jamnagar, India.

26. Anbarasu K, Thangakrishnan K, Arun BV, Chandran MR (1998) Assessmen of immune response in freshwater catfish (Mystus vittatus Bloch) to different bacterins of Aeromonas hydrophila. Indian Journal of Experimental Biology 36: $990-995$.

27. Thune RL (1982) Plumb JA. Effect of delivery method and antigen preparation on the production of antibodies against Aeromonas salmonicida in channel catfish. Progressive Fish Culturist 44: 53-54.

28. Chen CF, Kusuda RA (1996) Preliminary study on the adjuvant activity of henbane in oral vaccination of grass carp (Ctenopharyngodon idellus). J Huazhong Agric Univ 15: 157-161.

29. Williams DL, Yaeger RG, Pretus HA, Browder IW, McNamee RB, et al (1989) Immunization against Trypanosoma cruzi: adjuvant effect of glucan. In J Immunopharmacol 11: 403-410.

30. Cuesta A, Rodrı A, Esteban M A Meseguer J (2005) In vivo effects of propolis, a honeybee product, on gilthead seabream innate immune responses. Fish Shellfish Immunol 8: 71-80.

31. Tatefuji T, Izumi N , Ohta T, Arai S, Ikeda M, et al. (1996) Isolation and identification of compounds from Brazilian propolis which enhance macrophage spreading and mobility. Biol Pharm Bull 19: 966-970.

32. Sivaram V, Babu MM, Citarasu T, Immanuel G, Murugadass S, Marian MP (2004) Growth and immune response of juvenile greasy groupers (Epinephelus tauvina) fed with herbal antibacterial active principle supplemented diets against Vibrio harveyi infections. Aquaculture 237: 9-20

33. Punitha SMJ, Babu MM, Sivaram V, Shankar VS, Dhas SA, et al. (2008) Immunostimulating influence of Herbal Biomedicines on non-specific immunity in Grouper Epinephelus tauvina Juvenile Against Vibrio harveyi. Infection Aquaculture International 16: 511-523. 